\title{
Knowledge, Practices and Perceptions Related to Salt Use among 18-70 Year Old Adults in Gampaha District of Sri Lanka
}

\author{
Karunapema R.P. ${ }^{1}$, Arnold S.M. ${ }^{2}$, Karunapema R.P, D. D. ${ }^{3}$, Dharmakeerthi N. $^{4}$, Rajapaksha R.M.S.D. ${ }^{5}$ \\ 1,2,3,4,5 Ministry of Health, Sri Lanka
}

\begin{abstract}
Background: The World Health Organization has called upon all countries to reduce average population salt intake to $<5 \mathrm{~g} / \mathrm{day}$. In Sri Lanka, average adult salt consumption is around $13 \mathrm{~g} /$ day, which is far above the WHO recommended value.

Objective: To describe the knowledge and practices related to food salt use, among 18-70 year old adults in Gampaha district of Sri Lanka.

Methods: A cross sectional study was conducted in Gampaha district, Western province, Sri Lanka. Data were collected using a pre-tested self-administered questionnaire. Ethical approval was obtained from the Ethical Review Committee of Faculty of Medicine Ragama.

Results: The mean age of the study population is 44.3 years and male to female ratio is almost one. A majority (91.9\%) of the study participants identified high salt consumption leads to adverse health effects. Only $22 \%$ were able to identify the recommended maximum daily salt requirement. Many (78.4\%) respondents expressed cutting down on salt as an important health priority for them. Just over half of the $(50.4 \%)$ participants were carrying out some measures to reduce salt consumption. However, a large proportion $(88.2 \%)$ were of the opinion that they were using the correct amount of salt.

Conclusions: The level of knowledge about the maximum daily recommended amount of salt among the adult population is poor in Sri Lanka. Most participants were willing to cut down on salt provided they are enlightened with correct health messages.
\end{abstract}

KEYWORDS: Cardiovascular event, Hypertension prevention, Salt intake, Salt - knowledge and practices.

\section{INTRODUCTION}

High levels of dietary sodium are associated with raised blood pressure and adverse cardio vascular events[1].Epidemiological studies and clinical trials provide compelling evidence for a detrimental effect of sodium intake on blood pressure among both hypertensive and normotensive individuals[2-7].

There is a substantial variation of salt intake among different communities and countries. In the Inter Salt Study, the association between blood pressure and salt intake was studied in 52 communities with a wide range of salt intake[8]. Four of the communities studied had a low salt intake of $\leq 3 \mathrm{~g} /$ day and the rest had a salt intake of 6-12 g/day. The Inter Salt study showed there was a positive relationship between the salt intake and blood pressure[8].

Based on scientific evidence, the World Health Organization (WHO) has set a goal for worldwide reduction of dietary salt intake, and has called upon all countries to reduce average population salt intake to $<5 \mathrm{~g} /$ day[9].

Further, sources of sodium in the diet vary with the dietary pattern of the respective community. The INTERMAP study found that, of the People's Republic of China, most (76\%) dietary sodium was from salt added in home cooking, while in Japan most (63\%) dietary sodium came from soy sauce. Processed foods including breads, cereals and grains contributed heavily to sodium intake in the United Kingdom (95\%) and the United States (71\%)[10].

In Sri Lanka average adult salt consumption is around $13 \mathrm{~g} /$ day and the mean urinary sodium excretion is $8.6 \mathrm{~g} /$ day[11]. Around $70 \%$ of sodium intake among Sri Lankans came from salt added during cooking.

Salt reduction has been identified as a best buy strategy to reduce non communicable disease burden by the WHO[8]. National NCD policy and strategic framework has identified salt reduction as an important strategy [9]. Salt reduction strategy should be based on 


\section{International Journal of Current Science Research and Review}

ISSN: 2581-8341

Volume 04 Issue 11 November 2021

DOI: 10.47191/ijesrr/V4-i11-10, Impact Factor: 5.825

IJCSRR@ 2021

www.ijesrr.org

population dietary consumption pattern, knowledge and practices related to salt use and cultural acceptability of salt reduction intervention.

The knowledge about the harmful effect of salt, recommended maximum level, high salt containing foods, cooking practices and perception about the salt use are crucial for designing a effective salt reduction program[10].

This study was designed to capture the knowledge and practices related to salt use and perception related to reduction of salt among adult population in Sri Lanka.

\section{METHODS}

This study was conducted in Gampaha district, Western province from July to October 2013. We calculated the sample size based on the following formula $=\mathbf{Z}^{2}{ }_{1-\mathbf{a} / \mathbf{2}} \mathbf{P}(\mathbf{1 - P}) / \mathbf{d}^{2}$ and added $15 \%$ for non-response. The final sample size was 450. A multi stage cluster sampling method was employed to identify the households. One adult male or female (18-70 years) was recruited from each household. Data were collected using a pre-tested self-administered questionnaire. Ethical approval was obtained from the Ethical Review Committee of the Faculty of Medicine University of Kelaniya. Formal approval to conduct the study was obtained from the Regional Director of Health Services Gampaha. Informed consent was obtained from respective participants. Health volunteers in the selected villages supported the data collection. They were given training on the purpose of the study, method of household selection and data collection procedure by the principle investigator and co-investigators. All study participants were given a health education leaflet regarding correct use of salt by the health volunteers after completing the study.

Data were entered into EpiData, data entry software with in-built validity checks. Data analysis was done in SPSS version 16.0. Descriptive statistics were used to describe the findings.

\section{RESULTS}

The mean age of the study population was 44.3 years and male to female ratio was almost one. Majority (86.2\%) of the study participants were married. About half of the study population was employed. The response rate of the study was $82 \%$.

Table 1. Socio demographic characteristics of the population

\begin{tabular}{|l|l|l|l|}
\hline \multicolumn{2}{|l|}{$\begin{array}{l}\text { Male } \\
\text { N = Percentages }\end{array}$} & $\begin{array}{l}\text { Female } \\
\text { N = Percentages }\end{array}$ & $\begin{array}{l}\text { Total } \\
\text { N = Percentages }\end{array}$ \\
\hline Mean age (years) & 44.7 & 43.7 & 44.3 \\
\hline Marital status & $43(86.1)$ & 86.3 & 86.2 \\
\hline Married & 12.9 & 9.8 & 11.3 \\
\hline Unmarried & 1.0 & 3.9 & 2.5 \\
\hline Widowed & \multicolumn{2}{l}{} \\
\hline Education level (highest achieved) & 3.9 & 2.9 \\
\hline Up to grade 5 & 2.0 & 49.3 & 45.9 \\
\hline Up to O/L & 42.6 & 33.7 & 36.9 \\
\hline Up to A/L & 40.1 & 12.7 & 13.3 \\
\hline Tertiary education & 13.9 & \multicolumn{2}{l|}{} \\
\hline Employment & 75.2 & 32.7 & 53.8 \\
\hline Yes & 24.8 & 68.8 & 45.9 \\
\hline No & \multicolumn{3}{l}{} \\
\hline Family income (Rupees per month) & 8.8 & 6.7 \\
\hline Less than 6000 & 5.9 & 43.1 & 38.4 \\
\hline 6000-20000 & 33.7 & 25.0 & 26.1 \\
\hline 20001- 35000 & 27.5 & 22.1 & 26.0 \\
\hline Above 35000 & 30.2 & \\
\hline
\end{tabular}




\section{International Journal of Current Science Research and Review}

ISSN: 2581-8341

Volume 04 Issue 11 November 2021

DOI: 10.47191/ijesrr/V4-i11-10, Impact Factor: 5.825

IJCSRR@ 2021

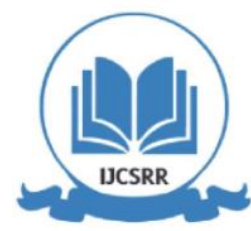

www.ijcsrr.org

Majority $(91.9 \%)$ of the study participants identified that high salt consumption causes bad health effects. $61.4 \%$ identified hypertension as the main health hazard. However, only $17.4 \%$ was able to correctly identify other health hazards such as stomach cancer, osteoporosis, kidney stones, etc. that are a result of high salt intake.

Maximum daily requirement of salt $(<5 \mathrm{~g} /$ day) was only identified correctly by $22 \%$. One quarter of the study participants $(25.1 \%)$ recognized $2.5 \mathrm{~g}$ as the required amount of salt per day.

Around half of the participants $(46.3 \%)$ had received some message on the importance of cutting down salt during the last year. Only $22.3 \%$ got the message from a member of health staff. Other important sources were television (17.4\%), news papers (13.8\%) and family members $(8.6 \%)$.

Forty one percent of the study participants were adding salt prior to cooking. A fairly lower percent (8.4\%) added salt after cooking. Powder form of salt was used by $29 \%$. Almost $41 \%$ of the subjects were eating home cooked meals in a given week while less than $6.7 \%$ was eating outside of home cooked meals more than four times per week.

Majority (78.4\%) of the respondents expressed cutting down of salt as a health priority for them. Half of the (50.4\%) participants were carrying out some measure to reduce salt consumption. Of those who reported taking action/s to lower their salt intake participants did so by reducing added salt during cooking $(53.7 \%)$, reducing processed food (36.3\%) and by reducing salty food $(25.7 \%)$.

There is a significant association $(0.05<\mathrm{p})$ between receiving a health message to cut down on salt and taking some measure to reduce salt consumption.

$\operatorname{Most}(88.2 \%)$ were on the opinion that they were using right amount of salt. However, almost $90 \%$ said they could further cut down on salt.

Table 2. Knowledge related to high salt use among the study population

\begin{tabular}{|l|l|l|}
\hline Domain Knowledge & Number & Percentage \\
\hline High salt bad for health & 374 & 91.9 \\
\hline Yes & 22 & 5.4 \\
\hline No & \multicolumn{2}{l|}{} \\
\hline What health hazards & 250 & 61.4 \\
\hline hypertension & 22 & 5.4 \\
\hline Osteoporosis & 5 & 1.2 \\
\hline Stomach cancer & 22 & 5.4 \\
\hline Kidney stone & 70 & 17.2 \\
\hline All of the above & 5 & 1.2 \\
\hline None of the above & \multicolumn{2}{l|}{} \\
\hline Required amount of salt per day & 102 & 25.1 \\
\hline 2.5 g/day & 90 & 22.1 \\
\hline $5.0 g /$ day & 55 & 13.5 \\
\hline 10.0 g/day & 18 & 4.4 \\
\hline $15.0 g / d a y$ & 142 & 34.8 \\
\hline Do not know & 333 & 81.8 \\
\hline Knowledge to correctly identify High salty foods & 59.7 \\
\hline Dried fish & 243 & 25.8 \\
\hline Soup cube & 105 & 62.8 \\
\hline Sauce & 254 & \\
\hline Murukku & & \\
\hline
\end{tabular}




\section{International Journal of Current Science Research and Review}

ISSN: 2581-8341

Volume 04 Issue 11 November 2021

DOI: 10.47191/ijesrr/V4-i11-10, Impact Factor: 5.825

IJCSRR@ 2021

Www.ijcsrr.org

Table 3. Practices related to salt use among the study population

\begin{tabular}{|c|c|c|}
\hline $\begin{array}{l}\text { Domain } \\
\text { Practices }\end{array}$ & $\begin{array}{l}\text { Number } \\
\mathrm{N}=\mathbf{4 0 7}\end{array}$ & Percentage \\
\hline \multicolumn{3}{|l|}{ How do you add salt } \\
\hline Before & 167 & 41.0 \\
\hline During cooking & 86 & 21.1 \\
\hline After & 34 & 8.4 \\
\hline More than one method & 116 & 28.5 \\
\hline \multicolumn{3}{|l|}{ Are you cutting down on salt } \\
\hline Yes & 205 & 50.4 \\
\hline No & 105 & 37.6 \\
\hline \multicolumn{3}{|c|}{ What methods are you Carrying out to reduce salt intake } \\
\hline Reduce adding salt & 108 & 26.8 \\
\hline Reduce processed food intake & 73 & 17.9 \\
\hline \multicolumn{3}{|l|}{ Adding spices } \\
\hline Reduce salty food & 51 & 12.5 \\
\hline \multicolumn{3}{|c|}{ Have you received any health advice to reduce salt (last 12 months ) } \\
\hline Yes & 188 & 46.2 \\
\hline No & 205 & 50.4 \\
\hline \multicolumn{3}{|l|}{ Source off such advice } \\
\hline Doctor & 53 & 13.0 \\
\hline Any other health staff & 38 & 9.3 \\
\hline Family member & 35 & 8.6 \\
\hline Television and radio & 71 & 17.4 \\
\hline News papers & 56 & 13.8 \\
\hline
\end{tabular}

\section{DISCUSSION}

Only a quarter of the study population was able to correctly identify the maximum recommended daily intake (RDI) of salt. There is a need to improve this specific knowledge with regard to maximum RDI in order to reduce the salt intake. However, when compared to our study findings with similar studies conducted elsewhere, our student population's knowledge on maximum RDI of salt seems to be much better.

In multi country web based study conducted by Newson et al found that knowledge about maximum RDI of salt intake is around 13\%[11]. The levels of knowledge on maximum RDI of salt for three countries were $10 \%, 24 \%$ and 3\% for India, China and USA respectively [11].In a study done in Australia in 2010, only 14\% were able to identify the RDI of salt[12].Further, four Latin American consumer associations found that only 3\% knew the maximum RDI of salt [13].This lower figure might be due to the open ended question posed to the study participants in Latin American multi country study.

The majority of the participants were able to identify hypertension as a bad health effect due to high salt intake and this was seen in most of the studies conducted to assesses the knowledge related to salt use[15 - 16]. However, knowledge related to other health hazards due to high seem to be poor among study participants. Hence, we need to educate the public about other health hazards posed by high salt intake.

Furthermore, It is interesting to note that fairly large percentage has identified the importance of cutting down of salt. Similarly, Newson et al reported readiness among study participants to cutting down on salt ranked 5.4 in a likert scale of 7 . The desire to reduce the salt consumption should come from the understanding that they are consuming too much salt and identifying health benefits of salt reduction [18]. Contradicting that most of the study participants believe they are consuming right amount of salt. Similarly in the multi country survey[11] the vast majority of the sample in every country thought that they were taking right amount 


\section{International Journal of Current Science Research and Review}

ISSN: 2581-8341

Volume 04 Issue 11 November 2021

DOI: 10.47191/ijesrr/V4-i11-10, Impact Factor: 5.825

IJCSRR@ 2021

www.ijcsrr.org

of salt. This poses a real challenge to convince people that they are consuming too much salt. This fact is confounded by lack of clear knowledge about maximum RDI of salt.

In the present study we have found that around half of the participants are carrying out some measure to cut down salt. However, this must be viewed with some caution considering the high per capita salt consumption reported in Sri Lanka[7]. This finding is also in contrary to the high urinary sodium execration $(8.6 \mathrm{~g} / \mathrm{day})$ in the adult Sri Lankan population as reported by the Medical Research Institute. The reason behind could be that either they may have expressed incorrectly or they have failed to reduce the salt consumption despite taking some action. Again majority said they were willing to cut down salt consumption and this might be indirectly suggesting that they are already consuming too much of salt.

\section{CONCLUSION}

This study finds that knowledge about the maximum RDI of salt is poor. Most of the participants were willing to cut down on salt with correct health message. Therefore, it is important to disseminate the correct information about the maximum RDI of salt intake through our health educational programs at both the individual level and population level.

\section{REFERENCES}

1. Brown IJ, Tzoulaki I, Candeias V, Elliott P. Salt intakes around the world: implications for public health. Int J Epidemiol. 2009;38(3):791-813.

2. Sacks FM, Svetkey LP, Vollmer WM, et al. Effects on blood pressure of reduced dietary sodium and the Dietary Approaches to Stop Hypertension (DASH) diet. DASH-Sodium Collaborative Research Group. N Engl J Med. 2001; 344(1):3-10.

3. Conlin PR. Eat your fruits and vegetables but hold the salt. Circulation. 2007;116(14):1530-1531.

4. Cutler JA, Follmann D, Allender PS. Randomized trials of sodium reduction: an overview. Am J Clin Nutr. 1997;65(2 Suppl):643S - 651S.

5. Midgley JP, Matthew AG, Greenwood CM, Logan AG. Effect of reduced dietary sodium on blood pressure: a meta-analysis of randomized controlled trials. JAMA. 275(20):1590-1597.

6. Graudal NA, Galløe AM, Garred P. Effects of sodium restriction on blood pressure, renin, aldosterone, catecholamines, cholesterols, and triglyceride: a meta-analysis. JAMA. 1998;279(17):1383-1391.

7. Elliott P, Marmot M. International studies of salt and blood pressure. Ann Clin Res. 1984;16 Suppl 4:67-71.

8. Elliott P, Stamler J, Nichols R, et al. Intersalt revisited: further analyses of 24 hour sodium excretion and blood pressure within and across populations. Intersalt Cooperative Research Group. BMJ. 1996;312(7041):1249-1253.

9. World Health Organization Forum on reducing salt intake in populations: Report of a WHO forum and technical meeting, 5-7 October 2006, Paris, France

10. Anderson CAM, Appel LJ, Okuda N, et al. Dietary sources of sodium in China, Japan, the United Kingdom, and the United States, women and men aged 40 to 59 years: the INTERMAP study. J Am Diet Assoc. 2010;110(5):736-745.

11. Choudhury SR.Current situation and capacity in the South-East Asia Region to report on the global voluntary targets: Salt/sodium intake. In: Technical Working Group Meeting on Regional Action Diseases, Targets for Prevention and Control of Noncommunicable Bangkok, Thailand.; 2013.

12. World Health Organozation, Ministry of Public Health and Public Development of Russian Federation. Discussion Paper on Prevention and Control of Non Communicable Diseases: Priorities for Investment. First Global Ministerial Conference on Healthy Lifestyles and Noncommunicable Disease Control. 2011;(April):28-29.

13. Non Communicable Diseases Unit, Ministry of Health, Sri Lanka. National Policy \& Strategic Framework on Injury Prevention \& Management in Sri Lanka. 2010.

14. World Health Organization. 2014. Fact sheet: Salt reduction. Viewed: http://www.who.int/mediacentre/factsheets/fs393/en/.

15. Newson RS, Elmadfa I, Biro G, et al. Barriers for progress in salt reduction in the general population. An international study. Appetite. 2013;71:22-31. 


\section{International Journal of Current Science Research and Review}

ISSN: 2581-8341

Volume 04 Issue 11 November 2021

DOI: 10.47191/ijesrr/V4-i11-10, Impact Factor: 5.825

IJCSRR@ 2021

www.ijjcsrr.org

16. Webster JL, Li N, Dunford EK, Nowson CA, Neal BC. Consumer awareness and self-reported behaviours related to salt consumption in Australia. Asia Pac J Clin Nutr. 2010;19(4):550-554.

17. Claro RM, Linders H, Ricardo CZ, Legetic B, Campbell NRC. Consumer attitudes, knowledge, and behavior related to salt consumption in sentinel countries of the Americas. Rev Panam Salud Publica. 2012;32(4):265-273.

18. Glanz K, Rimer BK, Lewis FM. The scope of health behavior and health education. In: Glanz K, Rimer BK, Lewis FM, editors. Health behavior and health education: Theory, research, and practice. 3rd ed. Jossey-Bass; San Francisco: 2002. pp. 3-21.

Cite this Article: Karunapema R.P., Arnold S.M., Karunapema R.P, D. D., Dharmakeerthi N., Rajapaksha R.M.S.D (2021). Knowledge, Practices and Perceptions Related to Salt Use among 18-70 Year Old Adults in Gampaha District of Sri Lanka. International Journal of Current Science Research and Review, 4(11), 1549-1554 